\title{
乳歯晚期残存例について
}

\section{On the persistenee of the milk teeth}

\author{
九州荬科大学口腔解剖学教室 (指導、灘吉咸夫教授) \\ 山 \\ 田博小小住啓 - \\ 九州雨科大学口腔細菌学教室（指導、大曲靖夫教授）
}

大 城 晋

\section{I 緒言}

人の乳愾は生後 10 万月前後より萠出し始好 $2 \sim 3$ 才 頃ては全く生えそ万う方、6〜11才頃の間には之等の 乳朄は全て脱落し代生菡之交換するすのである。然し 乍ら時として此の交換時期忍過ざても尚乳宩が残学し て代生藏の萠出を見ざる場合がある。所謂乳崡の晩期

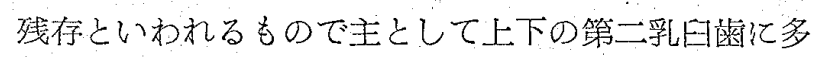
く出現し、次いで上顎第二乳切霜に見られる。而して 現在迄比乳莐晚期残存の報告例も可成り多く、羽时、 羽深、河合、牧山、新畑、野田、野呂、大过、竹松、 杤原其他の各氏亿よって研究せられている。吾々も今 回34才の女性に下顎第二乳臼柬力残存し、第二小曰蒾 の久除せる一例に遭遇したので先大の例に迫加して報 告する次第である。尚又之と例せて当教室所蔵の石高 模型中に22才の女性の上顎及び19才の男性の下顎に夫 々第二乳曰菌の睌期残存と第二小四歯の久除している の长報告する。

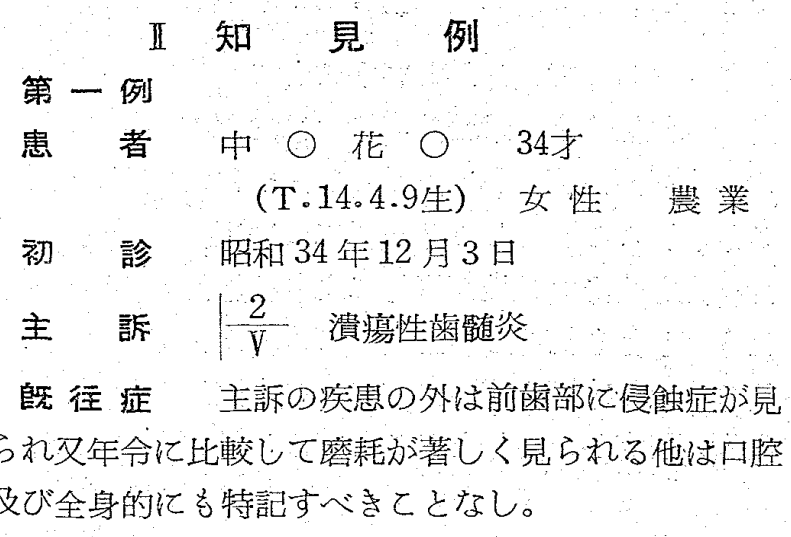

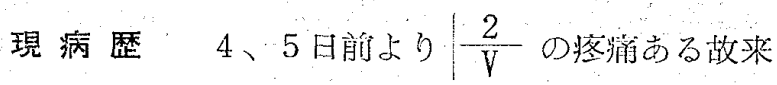
院

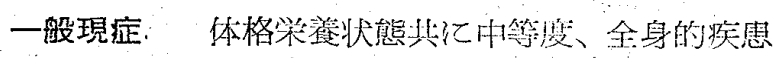

口腔外所見特記す可き牙項なし

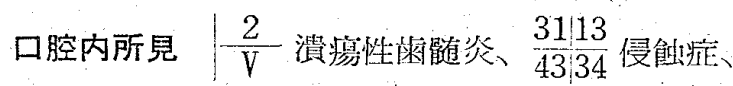

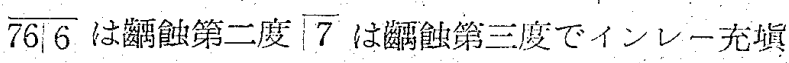

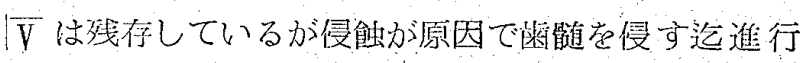

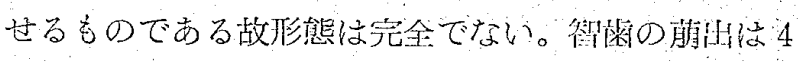
霜とも認少られない。

X線像所見 $\overline{\mathrm{V}}$ の菌根吸收は遠心根 $\rightarrow$ 根端部の吸

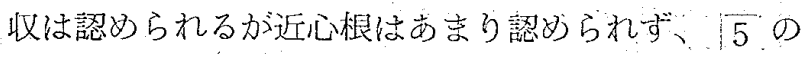

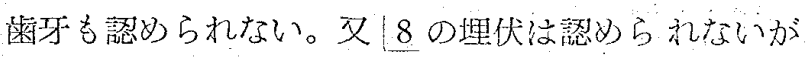
$\frac{81}{818}$ $\frac{8}{8} 8$ は埋伏しているのが認められた。

処置 $\frac{2}{V}$ は通法の加く処冝し終未期し

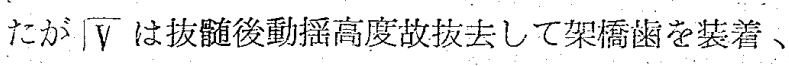

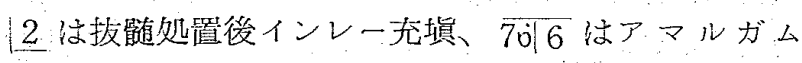
充填、 $31 \mid 13$ は3 はインン一立填す。

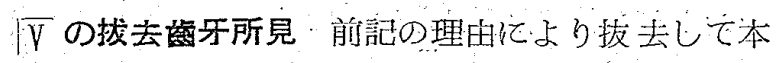

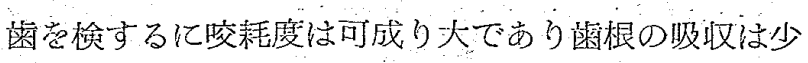

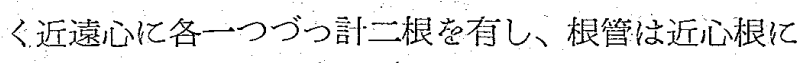

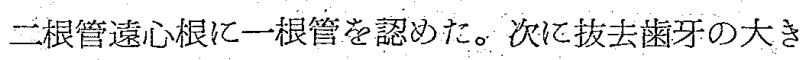
されついてその計測值を見ると次の如くである。 
表 I

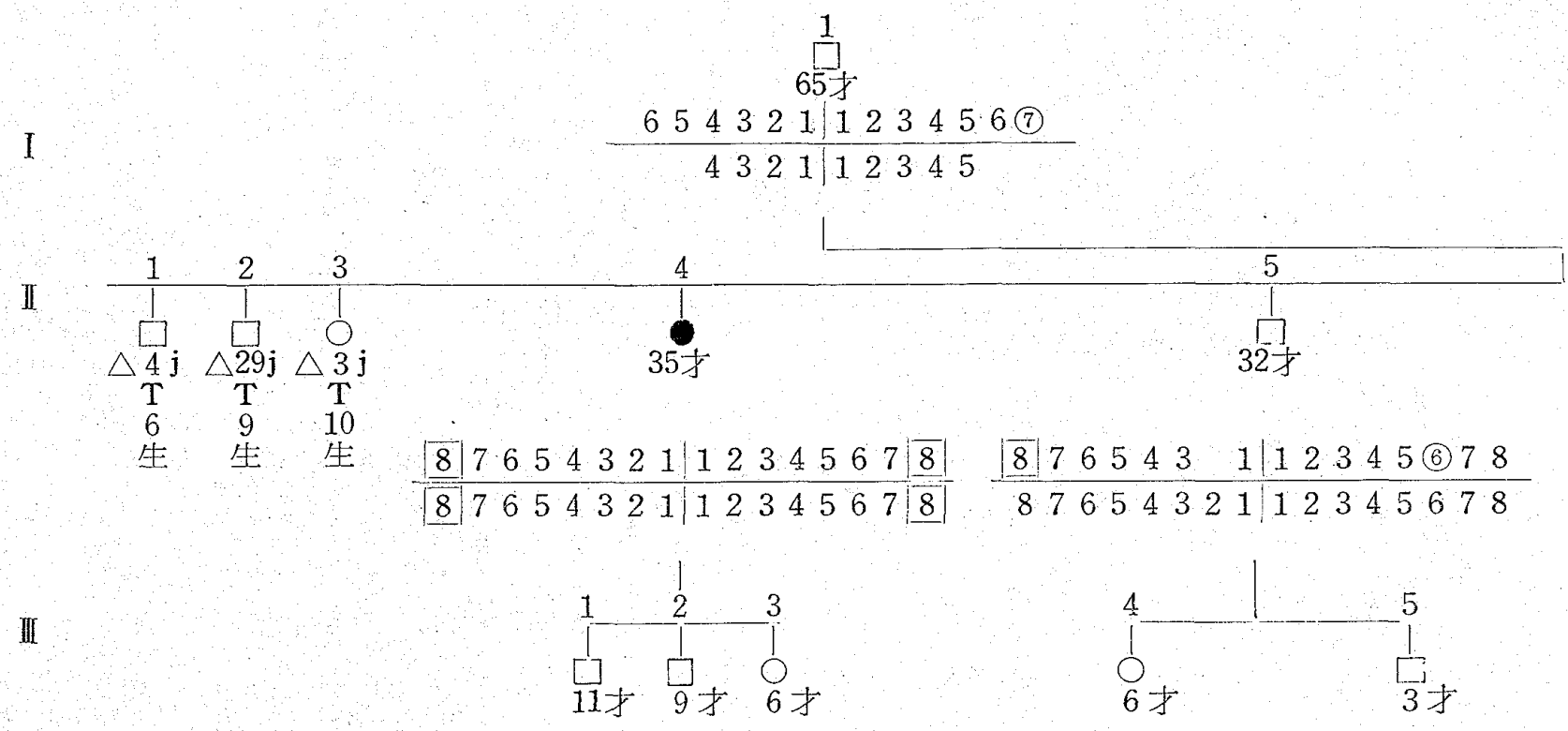

奌冠長径 $3.9 \mathrm{~mm}$ 、菌冠近遠心径、 $9.7 \mathrm{~mm}$ 、菌冠 煩舌堡、 $8.2 \mathrm{~mm}$ 、全長、 $10.8 \mathrm{~mm}$

家 族 歴本例は他の家族には表のI代番号 6 亿

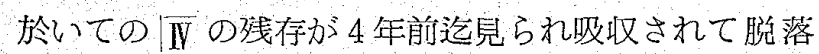
した他は别表の如く乳雪の㴔期残存は認められなふつ たが表のI代番号 1 及び 2 は前のととについては不 明である。又而代の1〜7迄は年令的に本例の刘称と はならない。尚正代番苛 6 の乳菡の萠出は 5 万月の初

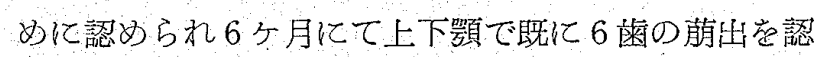
めたとの事である。表の1代番号 1 は后20年前に 水平智雪で抜去し、I代番号 2 引智雪の萠出方無い。 II 代番号 4 は本人である。

\section{第二例}

第二例及び第三例は何礼も当教室所截の石喨模型中 に於いて発見せられたものである。

模型番号 No. 636、22才 女性

上顎は $5 \mid$ が久如し其の位固に V|か洺存している。 其他では第二大曰幽迄全て萠出し智歯は末萠出で異常

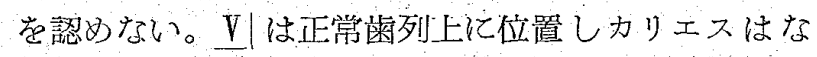
く晈耗度は大である。模型上に於ける調查であるため

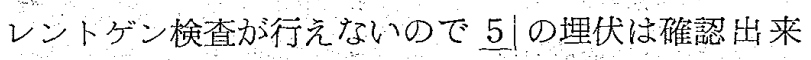
ない文 の菌根吸収の状態も不明である。

\section{第三例}

模型番号 No.622、19 才、男性

上顎は81780欠如以外には異常なく下頶は智歯
伎び 5 が久如し 5 の位置にV|が残存している。 之もレントゲン検査等は出来ず単なる模型上の調查で

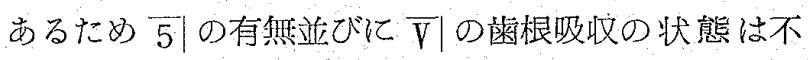
明である。淌17亿は稍々大なる四旁結節を認めた。

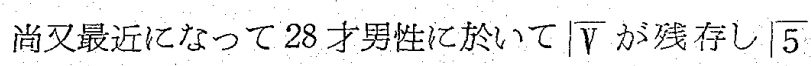
の久除せる症例に遭遇して目下調查营している。

\section{III 総括並びに考按}

乳菡の晚期残存については上下顎の第二乳曰蒾に最 も多く現われるが住谷氏の調查によると上顎では男性 $2 \%$ 女性 $3.8 \%$ 、下顎では男女共に $2.8 \%$ の出現率を 示している。其他の乳歯では何れも $1 \%$ 以下で上顎乳 中切雪には一例も認め得なかつたというととである。 而して之等の乳畨晚期残存に於いてはその後継代生歯 を欠如しているものである。徒って後縌菌の欠如によ る機能の代行者として永く乳䨑方浌存しているわけで ある。それならば何故第二孚四曾得も多く晩期残存 が見られるのであるかということに関しては、それが 全身的熱性疾患、栄養障碍或いは局所的外傷等により 後継虐牙が破褧されて朋出しなかつたという場合もあ るが、吾々の遭遇した第一例てついて㫕てる知去に前

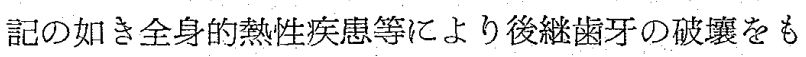
たらすか如き何等の原因的要素も見あたらない。文本

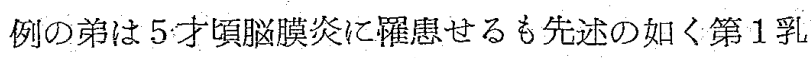
罒畨の残存があつたとのととであるが、玨々は之を人 類菌牙の退化現象として考えて見たのである。 


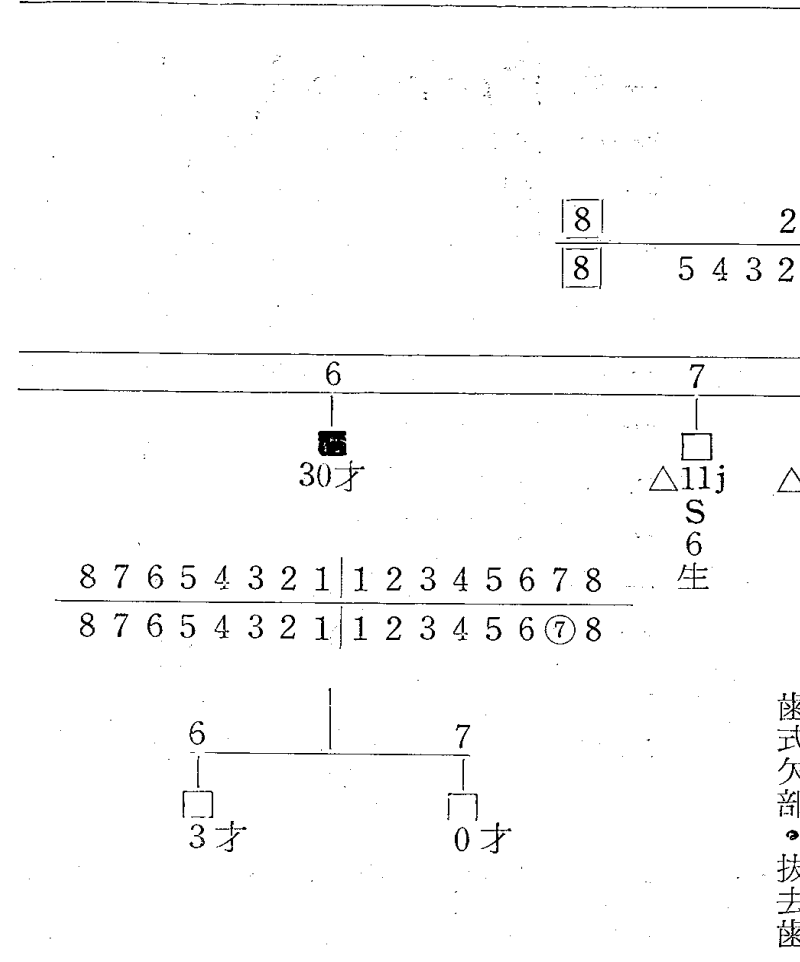

Bolk Terminale Reduktion に彷えば人の粜 は囷列の末端より退化しているのであって、第二小曰

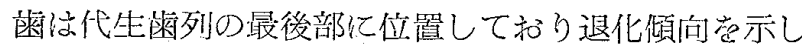
それが極端なる場合には久如しているととも当然考え

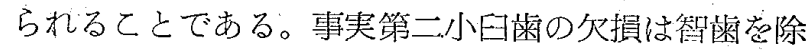
いては上颚側切畨と共に最す多いのである。即ち第二 小曰曾は現在退化の過程にある歯牙であってそれが更

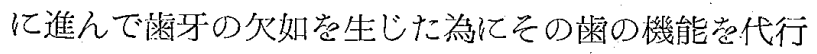

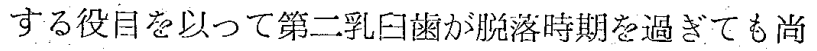
且っ线信しているのである。

乳菌の脱洛は主として後継柬牙の機械的圧迫により 柬根吸收を起して行われるのであるが、後継雨の方如 している場合でもその胎落時期に到れば乳茵自体の自 然的意退現象即ち生活力の低下か現われるもので多少 でも荬根力吸收されて来るが雪に年令が進むてつれて 荬根の吸収が進行し、次第に脱落の傾向を辿るむの之 考元られる。

然るに第一例の如く34才迄も整根の吸収方大して行 われずに残存していたというととは甚だ稀有なること である。

本例の如きは遺伝的なるのがあるか否かというとと については第一例に於引る本人の弟に於いて 25 才頃迄 下顎左側第一乳田米の残保力認められた以外は不明で ある。従つて本問題に関しては確実なととは分らな w。

2
0
$65 才$
$1 \mid 1$
$1 \mid 123$

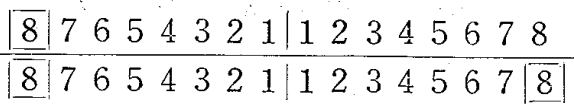

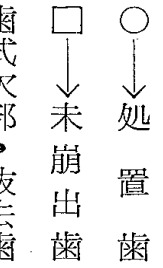

\section{IV 結 論}

吾々は第二乳曰宩の残存之第二小曰米の欠如せる例 亿遭遇した。

第一例は34才の女性で下顎左側第二乳巨缹の晚期残 存で後継代生菡である第二小四雨は久除していた。又 頲㑂的関係については不明であるが本人の晹に25才頃

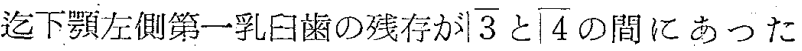
というととである。然し現在では脱落している。

第二例は22才の文性で VI、又第三例は19才の男性 で $\overline{V \mid}$ が夫及残存し且っ㷋継代生菡党欠如していて。

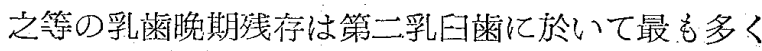

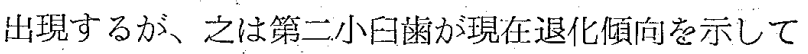

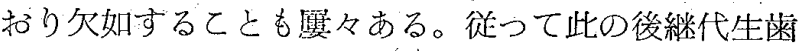
の機能を代行するために脱洛時期空過ぎても永く乳菌 か戦倍しているものである。

\section{參、考文献}

1）朽原義人、横山国滉：第二乳四歯全部晚期浅存 例（九州歯科学会猚誌 1 、昭和 8 年)

2）狗田宣男：下顎乳E畨晚期残存に第二小曰畨先

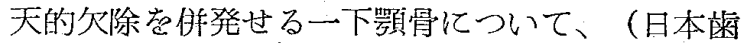
科学会雑誌第26巻 8 号、昭和 8 年)

3）河合卓治：成人に於いて対称性に現われたる乳

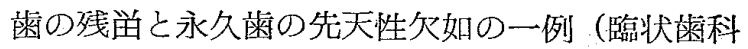
11、昭和14年)

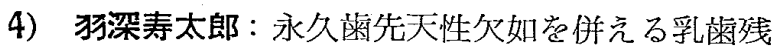


畄の対顎に過㮃歯有する一例、（臨状歯科12、 服和15年)

5) 新畑小一郎：継承永久荬を欠如して晩期残存せ る人類乳歯に関する研究、（日本之歯界222、昭和 13年)

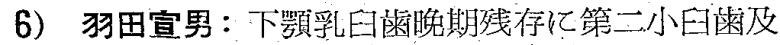
び側截崡の先天的欠如堂仿発せる一例、（臨状歯 科 9 、昭和12年)

7）住谷 靖：日本人に扣ける画の異常の統計的観 察、(人類学雑誌第 67 巻第 4 号、昭和 34 年)

8）藤田恒太郎：粦の解剖学

\section{写真 説 明}

(1) 中○花 $\bigcirc$ 壬 34 才 VI 晚期线存

(2) 40 批 古 34 才 咬合関係 正面

(3) 中○花 $\bigcirc 34$ 咬合関係 側面 (左)

(4) 中○仳 古 34 才 咬合関係 側面（存）

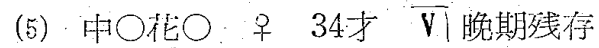

(6)：第一例 $\sqrt{\mathbf{V}}$ のレントゲン像

(7) 第一例 反対側のレントゲン像

(8)：第一例８|のレントゲン像

(9)、第一例 18 のレントゲン像

(10)第一例 $\overline{8} \mid$ のレントゲン像

(11) 第一例 $\overline{8}$ のレントゲン像

(12) 第一例. $\mathrm{I}$ の類側

(13) 第一例

(14) 第一例 $\cdot \overline{\mathrm{V}}$ の咬合面

(15) 第一例“本人の弟 下顎左側のレントゲン像

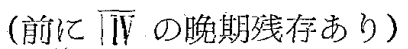

(16). 第一例 本人の弟

(17) 第二例 No.636、22才、、、ㄴ 晚期残存、 $5 \mid$ 欠損

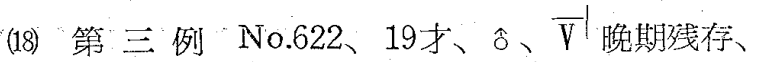
$\overline{5}$ 久損、 $\overline{7}$ 曰旁結節

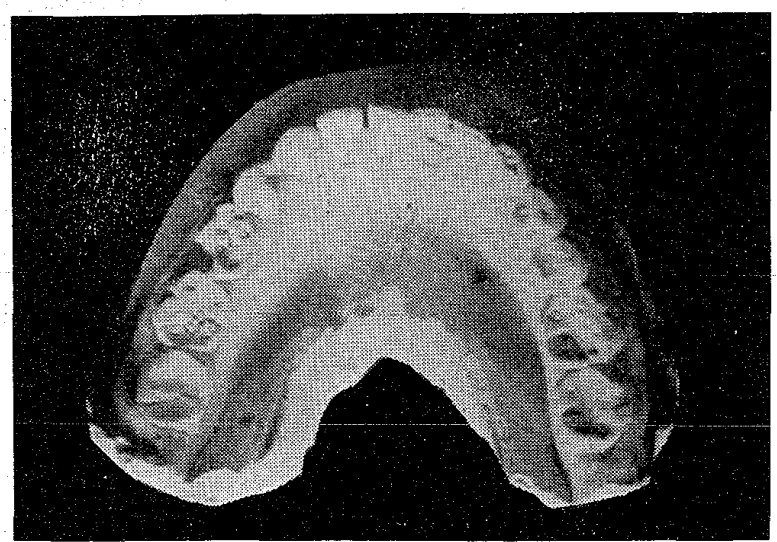

(1)

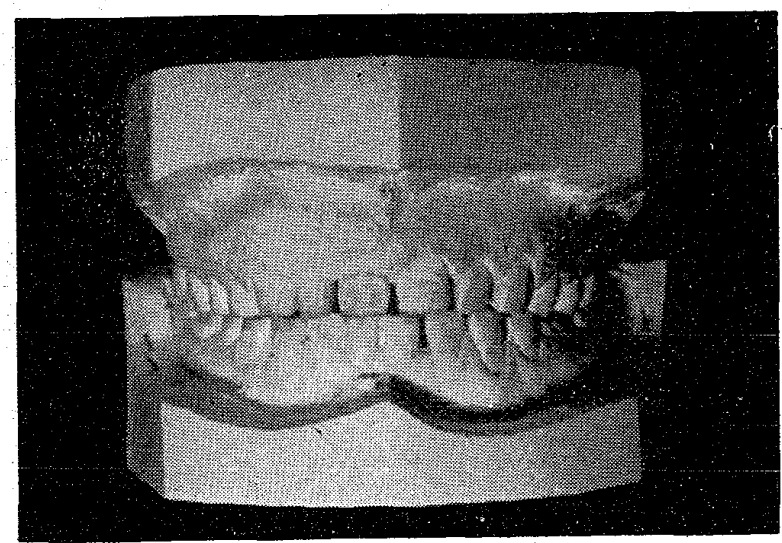

(2)

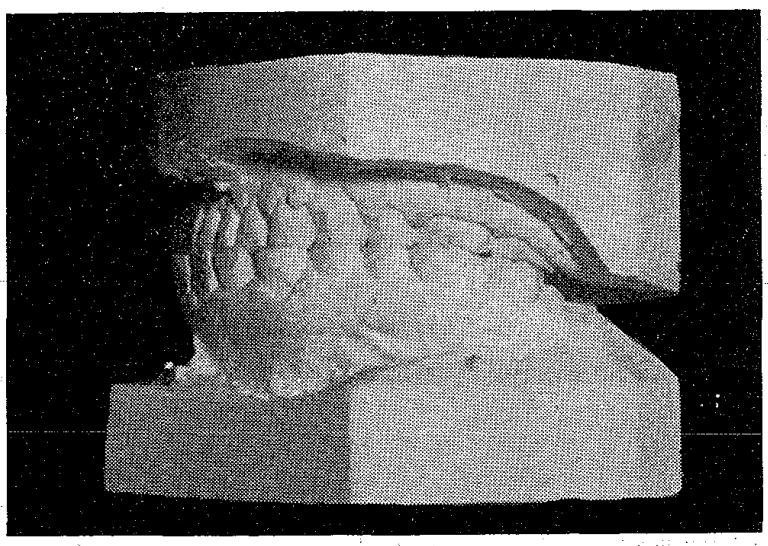

(3)



(4) 


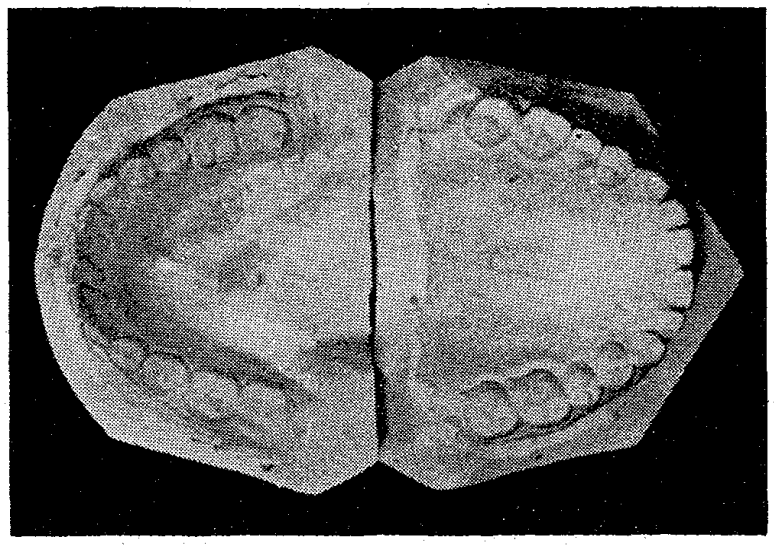

(5)

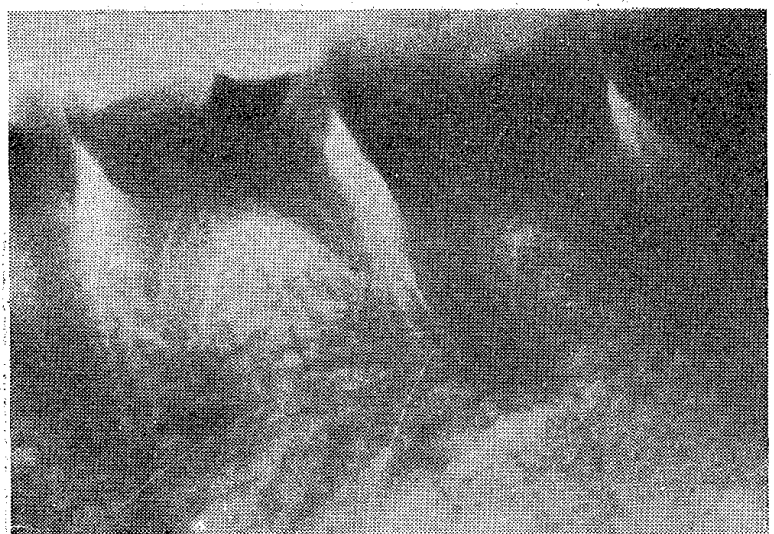

(6)

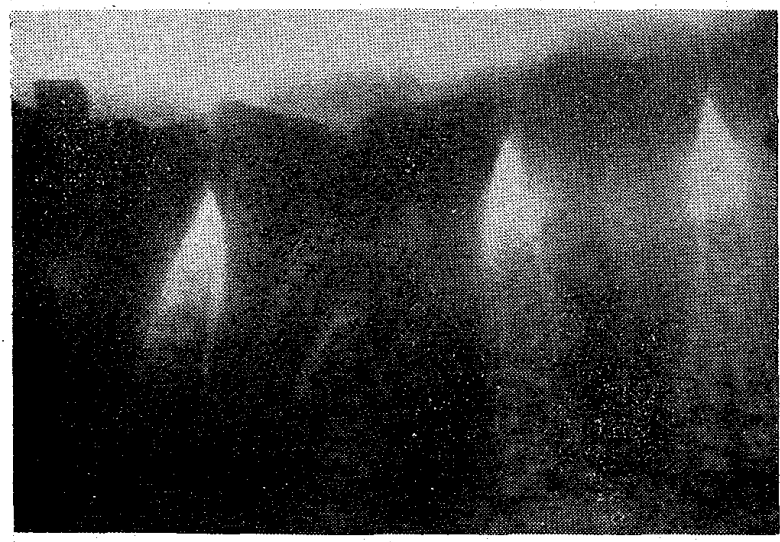

(7)

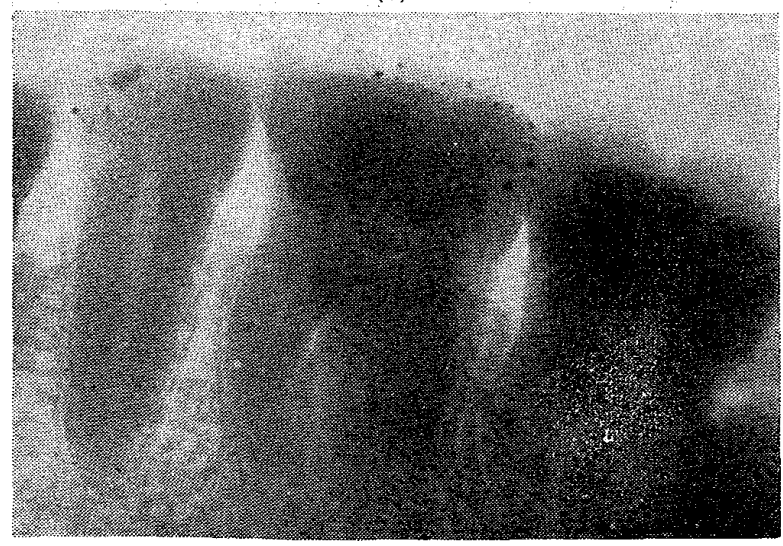

(8)

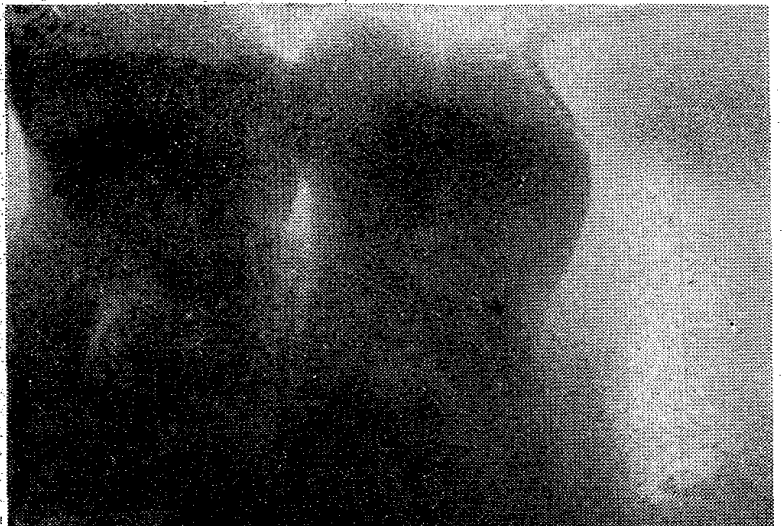

(9)

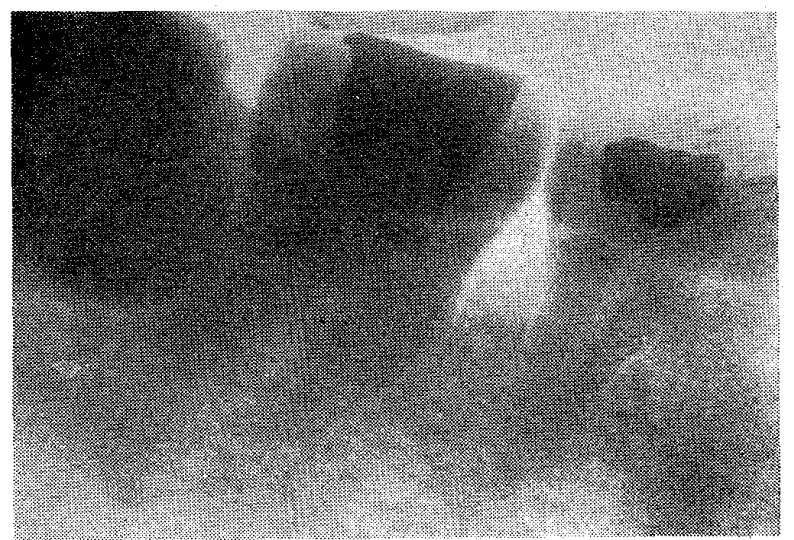

(10)

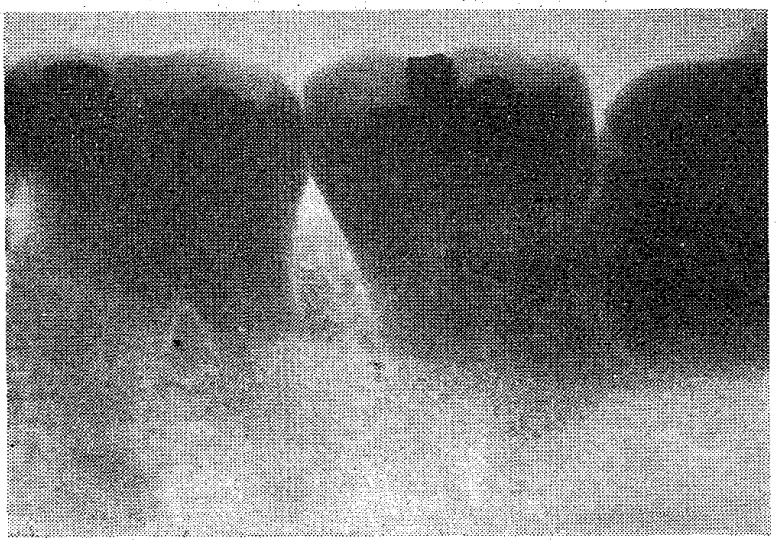

(11)

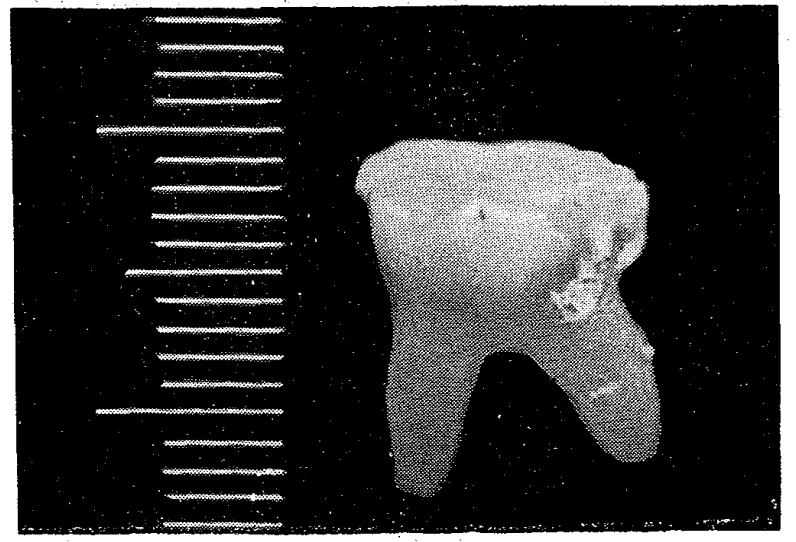

(12) 


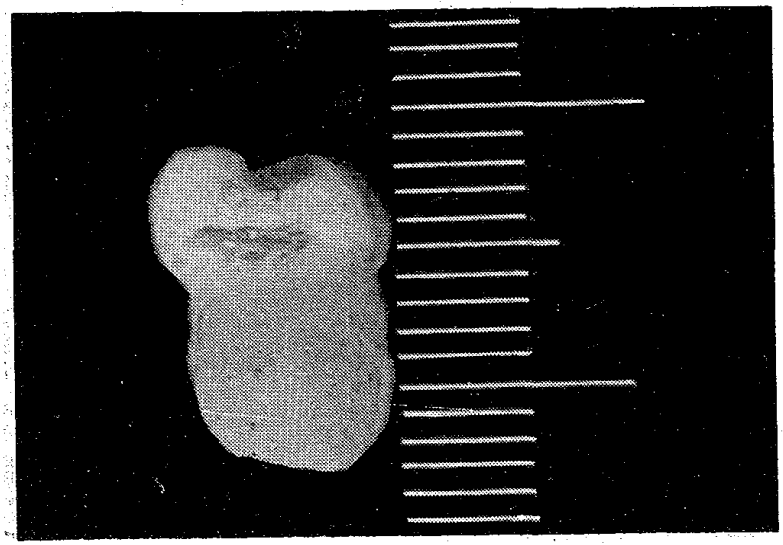

(13)

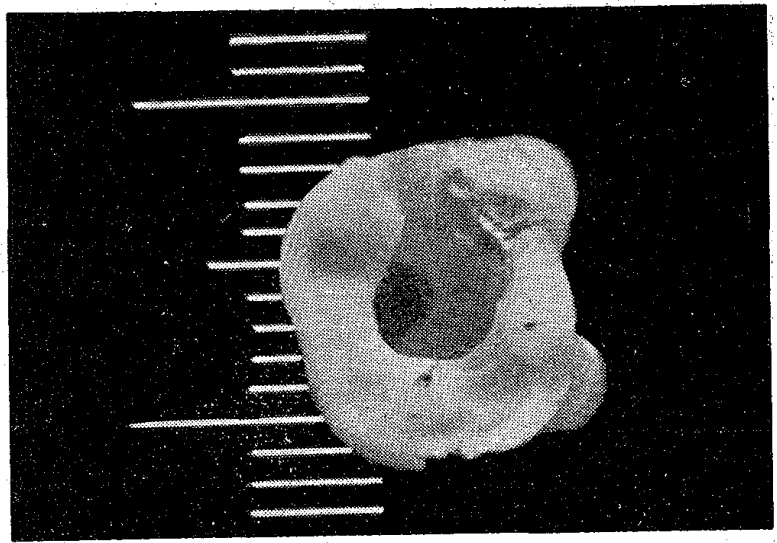

(14)

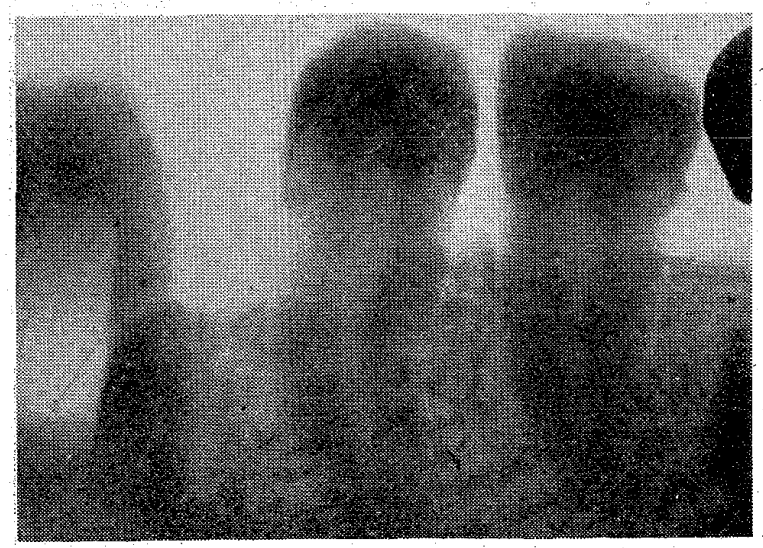

(15)

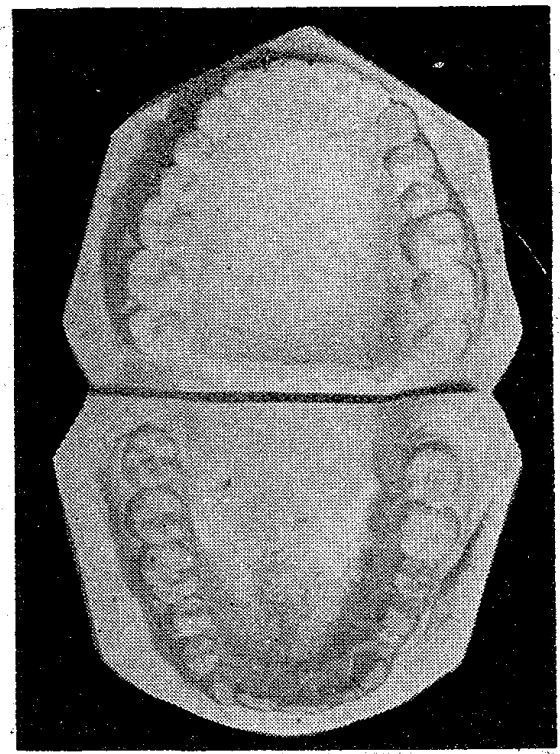

(16)

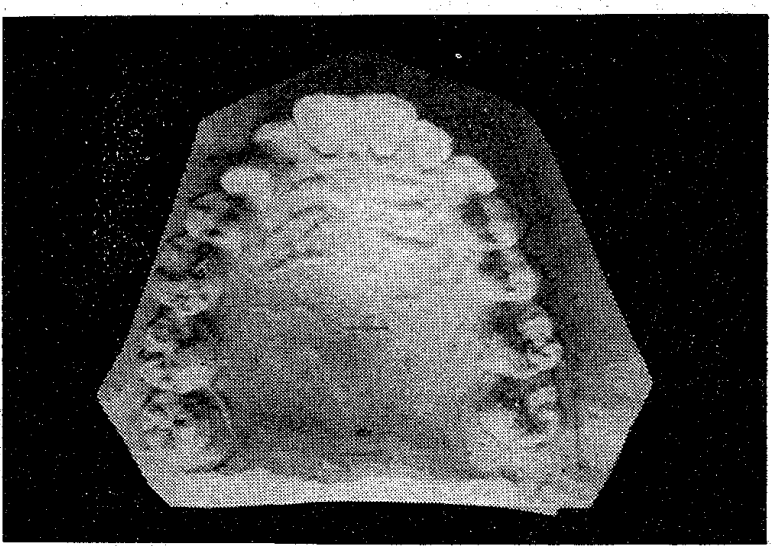

(17)

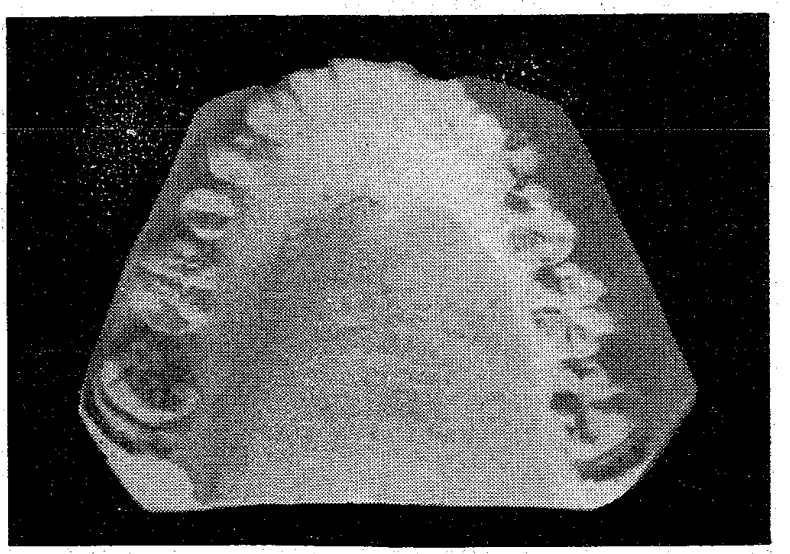

(18) 